\title{
Recent advances and conceptual changes in the classification of neuroendocrine tumors of the thymus
}

\author{
Hanibal Bohnenberger ${ }^{1} \cdot$ Philipp Ströbel $^{1}$ (D) \\ Received: 11 September 2020 / Revised: 9 December 2020 / Accepted: 17 January 2021 / Published online: 8 February 2021 \\ (C) The Author(s) 2021
}

\begin{abstract}
Neuroendocrine tumors of the thymus (TNET) are exceedingly rare neoplasms. Their histomorphology is identical to neuroendocrine tumors elsewhere in the body (in particular the lungs) and bears no similarity with thymomas and thymic carcinomas. Recent molecular findings have profoundly changed our perception of these tumors and may impact future histological classification systems.
\end{abstract}

Keywords Neuroendocrine - Carcinoid · Atypical · Large cell neuroendocrine carcinoma · NET G3 · Thymus · Molecular · Classification · World health organization · Sequencing

\section{General features of thymic neuroendocrine tumors}

Neuroendocrine tumors of the thymus (TNET) are exceedingly rare neoplasms. Their histomorphology is identical to neuroendocrine tumors elsewhere in the body (in particular the lungs) and bears no similarity with thymomas and thymic carcinomas. Based on the many shared features between pulmonary and thymic NET, TNET and pulmonary NET (PNET) are traditionally classified using the same criteria into typical and atypical carcinoids (TC and AC), large cell neuroendocrine carcinomas (LCNEC), and small cell carcinomas. Although previous studies found genomic differences between pulmonary and thymic TC and AC [19, 32], there are currently no immunohistochemical markers that allow distinction between TNET and PNET in the absence of clinical and imaging data (Table 1). Of note, most thymic and pulmonary carcinoids are negative for TTF1 [18, 26, 33]. There are however a few interesting differences in the epidemiology of TNET and PNET: thymic TC and AC show a strong male predominance, while pulmonary

Philipp Ströbel

philipp.stroebel@med.uni-goettingen.de

1 Institute of Pathology, University Medical Center Göttingen, Robert-Koch-Str. 40, D-37075 Göttingen, Germany carcinoids occur more often in females. AC and LCNEC are by far the most frequent subtypes in the thymus, while SCC and TC prevail in the lung. Most patients with pulmonary LCNEC and SCC are heavy smokers, while there is no established role of smoking in the development of any NET type in the thymus. There are also important epidemiological differences among the different TNET subtypes: as mentioned above, there is a striking male predominance (males are affected 3 to 6 times more frequently) for TC and AC, while LCNEC and SCC affect males and females equally. MEN1 is a risk factor only for TC and AC, while LCNEC and SCC are not observed in this setting. These observations are important because they point to substantial differences between low-grade (TC and AC) and high-grade (LCNEC and SCC) TNET. Most patients present with local symptoms (chest pain, cough, dyspnea, or superior vena cava syndrome) [11, $22,30]$. The vast majority of patients with paraneoplastic syndromes due to ectopic hormone production have TC or AC. These include Cushing syndrome (17-30\%) [7, 30, 34], hypercalcemia/hypophosphatemia [42], or hyperparathyroidism [35]. In stark contrast to thymomas, TNET have a high propensity for regional lymph node metastases and $>50 \%$ of patients show involvement of regional lymph nodes at diagnosis [38]. The histological subtype is prognostically relevant: 5-year survival rates decrease from $50-70 \%$ in $\mathrm{TC}$ and $\mathrm{AC}[8,22,30,32]$ to $30-66 \%$ in LCNEC $[3-5,9,20,24,25,29,32,36]$ and to $0 \%$ (median survival 13-26 months) in SCC [17, 23, 32, 36, 
Table 1 Immunohistochemical profiles of TNET $(n=45)^{*}$

\begin{tabular}{llllllll}
\hline$\%$ positive cases & CGA & EZH2 & TTF1 & Pax8 & CD5 & CD117 & Calcitonin \\
\hline TC $(n=10)$ & 100 & 0 & 0 & 60 & 10 & 10 & 11 \\
AC $(n=24)$ & 100 & 4 & 0 & 42 & 8 & 13 & 4 \\
LCNEC $(n=8)$ & 50 & 50 & 25 & 63 & 38 & 25 & 0 \\
SCC $(n=3)$ & 0 & 100 & 0 & 0 & 0 & 0 & 0 \\
\hline
\end{tabular}

$T C$ typical carcinoids, $A C$ atypical carcinoids, $L C N E C$ large cell neuroendocrine carcinomas, SCC small cell carcinomas, $C G A$ chromogranin A; TTF1 clone: $8 \mathrm{G} 7 \mathrm{G} 3 / 1$; *unpublished own results and $[37,43]$
39]. The significant variation of published survival data in LCNEC is remarkable and points to a marked heterogeneity of the tumors analyzed.

\section{Molecular findings in TNET}

There are few published data on genomic features of TNET $[8,21,27,32]$ and virtually no data on the mutational spectrum of these tumors. One of the largest studies to date [32] using comparative whole-genome hybridization $(\mathrm{CGH})$ found an incremental increase of genomic alterations from $\mathrm{TC}$ to $\mathrm{AC}$ and $\mathrm{LCNEC} / \mathrm{SCC}$ that correlated with survival. Moreover, this study reported gene amplifications of MYC in LCNEC. A follow-up study using low-coverage ("shallow") whole-genome sequencing confirmed this observation but found also a significant overlap between the profiles of $\mathrm{AC}$ and LCNEC [8]. The primary objective of this study was to use genomic data as "ground truth" in comparison to the histological classification according to current world health classification (WHO) criteria (Table 2). To compare individual cases and classes, the mapped reads were counted in windows ("bins") along the chromosomes. The percentages of bins above/below the thresholds were calculated as a general measure of the amount of copy number aberrations present in each tumor (chromosomal instability score, CNI). Using this approach, the study identified three major molecular clusters with low (cluster 1), intermediate (cluster 2), and high CNI scores (cluster 3), for which cutoff values were statistically determined. Somewhat unexpectedly, this approach revealed significant "cluster infidelity" among the morphologic TNET subtypes: cluster 1 with few genomic alterations and low CNI score contained most TC and AC but also 4 LCNEC. In contrast, cluster 3 with most genomic alterations and highest CNI contained most LCNEC and all SCC but also 3 AC (Fig.1a). In addition, the authors found two extreme outliers: one atypical carcinoid with a very high CNI and one case classified as LCNEC according to WHO criteria (16 mitoses per $2 \mathrm{~mm}^{2}$ ) with very low CNI. Another highly informative observation came from a few cases where materials from the primary tumor and syn- or metachronous metastases were available (Fig. 1b). These cases showed heterogeneity between primary tumors and their metastases: patients had primary tumors classified, e.g., as typical carcinoid and metastases classified as LCNEC. A comparison of the genetic features of these cases showed mostly overlapping features with some additional alterations in the more progressed lesions. Remarkably, all of these cases belonged to the molecular clusters 1 and 2 with few and moderate numbers of chromosomal changes. Together, these observations have important implications: (1) The correlation between morphology and genetic complexity in TNET is imperfect - cases with "low-grade" morphology can have complex genetic features and vice versa. The same study showed that the molecular classification had at least the same prognostic relevance as current histologic classifications including WHO. (2) Cases that fall into the molecular clusters with low and intermediate complexity (cluster 1 and 2) form a spectrum, where morphological and molecular progression can occur. This spectrum includes cases that were classified as LCNEC according to current WHO criteria (these cases were provisionally termed NET G3 for better distinction from bona fide LCNEC within the highly complex cluster 3). (3) Progression of tumors from the molecular clusters 1 and 2 to the high-grade cluster 3 was not observed in this study and remains to be shown (in analogy to NET in other organs), suggesting at least two alternative molecular routes: the "low/intermediate" route that can lead to TC, AC, and NET G3 and the "highgrade" route that leads to SCC and LCNEC.

\section{Cases currently classified as LCNEC according to WHO criteria contain a group of tumors overlapping with carcinoids ("NET G3")}

In consequence of the conclusions described above, the authors next compared the NET G3 cases from the molecular clusters 1 and 2 to the "bona fide" LCNEC from the high-grade cluster 3 using a panel of immunohistochemical antibodies initially proposed by Yachida et al. [41] for the subtyping of pancreatic NET together with 


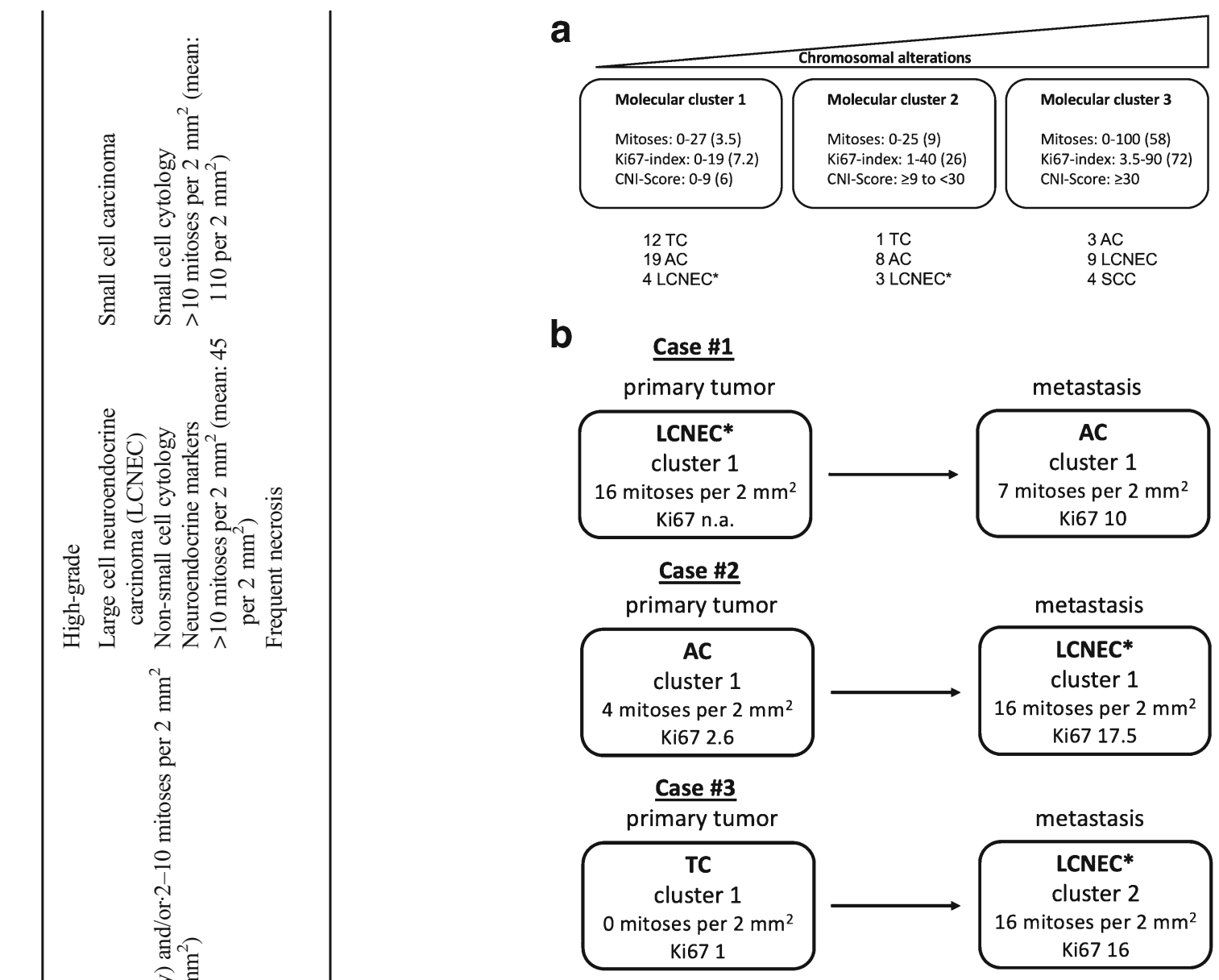

Fig. 1 Molecular findings with impact on the conceptual classification of thymic neuroendocrine tumors (TNET). (a) Low-coverage whole-genome sequencing revealed three major molecular clusters with few (cluster 1), moderate (cluster 2), and high (cluster 3 ) numbers of chromosomal alterations. The numbers of chromosomal alterations were quantified using a chromosomal instability index (CNI-score). The graph depicts the distribution of histological subtypes among the three clusters (TC typical carcinoid, AC atypical carcinoid, $L C N E C$ large cell neuroendocrine carcinoma) - cases marked with * were later re-classified as neuroendocrine tumors G3 (NET G3). SCC small cell carcinoma. (b) Comparison of three individual cases where more than one material was available

limited next-generation sequencing of selected genes. The two groups showed substantial differences. NET G3 invariably had carcinoid morphology (trabecular growth patterns, delicate vasculature, pepper-and-salt chromatin), while most LCNEC showed cytologic high-grade features (Fig. 2). Although LCNEC showed much higher ki67 and mitotic indices on average, these features were not helpful for the distinction of individual cases due to considerable overlap between the two groups. The best immunohistochemical markers for the distinction of NET G3 and LCNEC were chromogranin and EZH2: chromogranin was positive in all NET G3 but was lost in 4 out of 5 LCNEC (Fig. 3). Vice versa, 

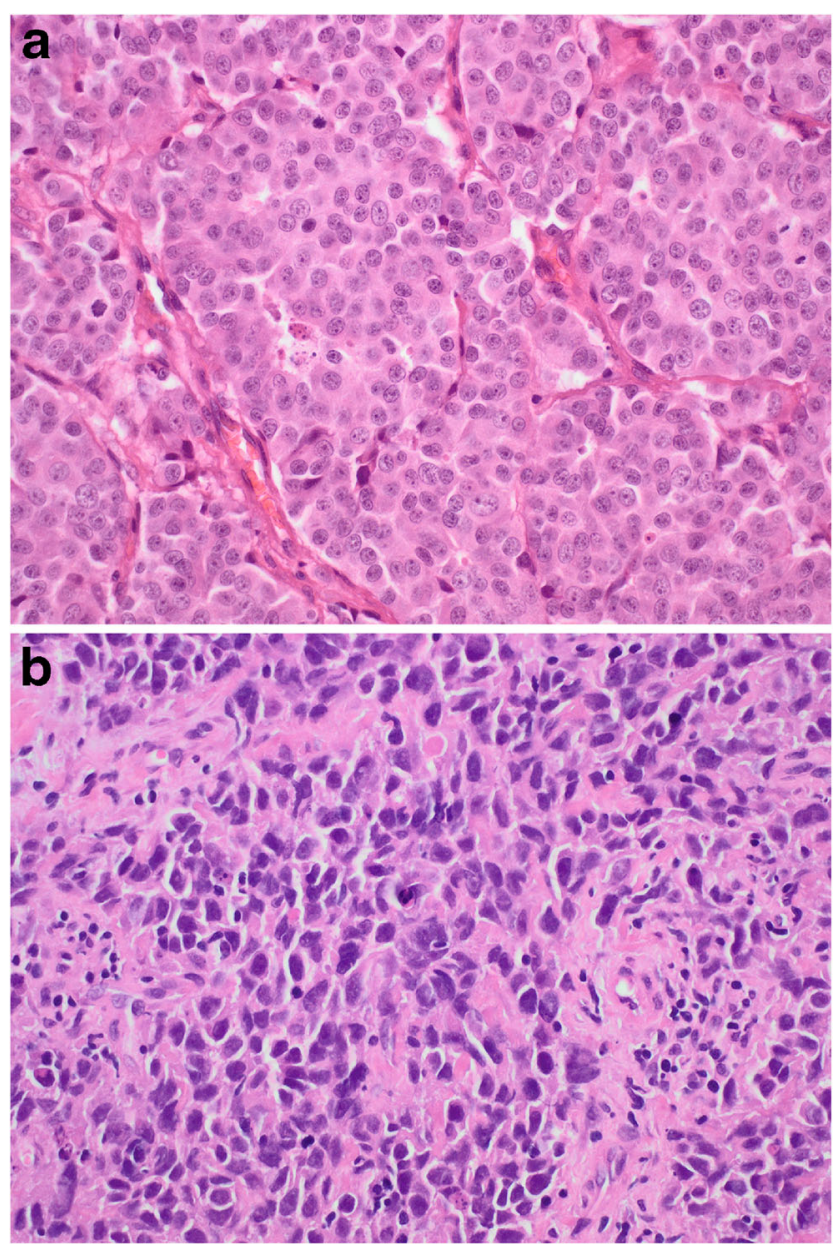

Fig. 2 Representative histological images of neuroendocrine tumors G3 (NET G3) (a) and large cell neuroendocrine carcinomas (LCNEC) (b)

EZH2 was negative in NET G3 and positive in LCNEC. Patients with EZH2-positive tumors showed a significantly shorter overall survival than patients with EZH2-negative tumors. EZH2 is a methyltransferase and is the functional component of the polycomb repressive complex 2 and a potent negative regulator of gene expression [6]. Overexpression of EZH2 is associated with poor survival, increased proliferation, and overexpression of TP53 [10] in many cancers including aggressive lung and gastrointestinal NET [2, 10]. Nextgeneration gene panel sequencing showed a single mutation of the gene encoding for alpha-thalassemia/mental retardation, X-linked $(A T R X)$ in a NET G3. ATRX is a transcriptional regulator that belongs to the SWI/SNF family of chromatin remodeling proteins. ATRX and death-domain-associated protein (DAXX) interact with one another and are required for deposition of histone H3.3 at telomeres and other genomic repeats [40]. There is a strong correlation between ATRX and DAXX mutations and an alternative lengthening of telomeres (ALT) phenotype in pancreatic NET $[12,14]$. Immunohistochemistry is a sensitive and specific screening tool for ATRX and DAXX mutations [12-14]. Although the loss of ATRX/DAXX and ALT in pancreatic NET is generally associated with tumor aggressiveness and reduced progression-free survival, these features are associated with better overall survival in the sub-cohort of metastatic patients [15]. In addition, the analysis revealed an unexpectedly high frequency of neurofibromin gene (NF1) mutations in $100 \%$ of NET G3 and LCNEC. NF1 inhibits RAS/MAPK signaling and is mutated in many cancers including soft tissue sarcomas, desmoplastic melanomas, and lung cancers [16].

\section{Conclusions and futures perspectives}

Together, these findings lead to important conceptual changes in the classification of TNET (Table 3). Although the mitotic index is an important tool that helps to stratify patients and to predict prognosis [32], the current mitotic thresholds used to classify TNET in the WHO classification (maintained also in the upcoming version) are insufficient to cover the whole spectrum of tumors. Molecular findings indicate that TC, AC, and the recently discovered NET G3 form a continuum where morphologic and molecular progression can occur, e.g., during relapses or in metastases. These tumors share the expression of chromogranin and somatostatin receptor 2A (SSTR2A) in the absence of significant EZH2 expression. The stainings for TP53 and RB are unremarkable ("wild type"). Some tumors harbor mutations of $A T R X$ (and presumably $D A X X$ ). Mitotic counts and ki67 index are usually much higher in true LCNEC and SCC, which often show loss of chromogranin and SSTR2A staining and overexpression of EZH2, accompanied by overexpression or complete loss of TP53 and/or RB1. Given the many similarities of TNET with NET in other organs, it is likely that the distinction between NET G3 and LCNEC will have therapeutic relevance: clinical experience has shown that gastrointestinal NET G3 show only limited response to platinum-based chemotherapy regimens used to treat patients with neuroendocrine carcinomas [28]. Recent molecular studies have identified a 


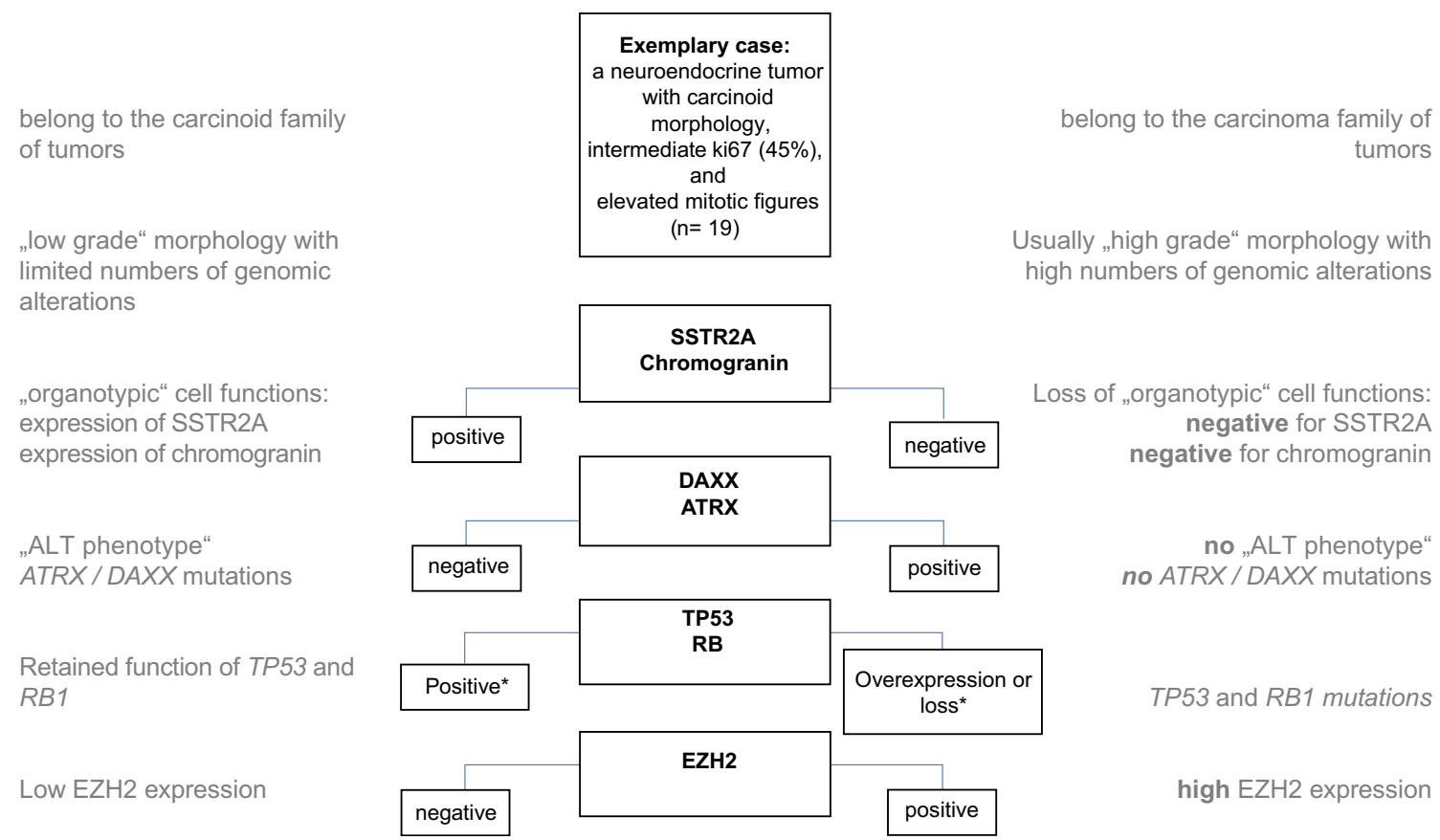

Fig. 3 Immunohistochemical findings aiding in the distinction between neuroendocrine tumors G3 (NET G3) and large cell neuroendocrine carcinomas (LCNEC). *Immunohistochemical TP53 stainings suggestive of TP53 gene mutations include overexpression and complete negative staining of tumor cell nuclei

current concept will aid in clinical decisions and the design of scientific or clinical studies. Further work will be necessary to better characterize the mutational and gene expression or proteomic profile of thymic neuroendocrine tumors in comparison to the much better studied pulmonary NET.

Table 3 Evolving concept for the classification of thymic neuroendocrine tumors based on molecular data

\begin{tabular}{|c|c|c|}
\hline Evolving concept & Low- and intermediate-grade NETs (TC, AC, NET G3) & High-grade NET (LCNEC, SCC) \\
\hline $\begin{array}{l}\text { Immunohistochemical } \\
\text { and molecular } \\
\text { features }\end{array}$ & $\begin{array}{l}\text { Tumors showing characteristic morphological and } \\
\text { immunohistochemical neuroendocrine features } \\
\text { NET G3 shows increased mitotic counts }\left(11-27 \text { per } 2 \mathrm{~mm}^{2} \text {, }\right. \\
\text { mean 16.8) and ki67 index (15-66\%, mean } 30 \%) \\
\text { Low to intermediate numbers of chromosomal alterations } \\
\text { ATRX gene mutations } \\
\text { Somatostatin receptor (SSTR2A) positive } \\
\text { Chromogranin positive } \\
\text { EZH2 negative }\end{array}$ & $\begin{array}{l}\text { High-grade morphology, often with loss of one or } \\
\text { more immunohistochemical neuroendocrine } \\
\text { markers } \\
\text { High mitotic counts }\left(12-100 \text { per } 2 \mathrm{~mm}^{2} \text {, mean }\right. \\
\quad 43.4 \text { ) and high ki67 index }(52-90 \% \text {, mean } 66 \%) \\
\text { High numbers of chromosomal alterations } \\
\text { No ATRX gene mutations } \\
\text { Somatostatin receptor (SSTR2A) negative } \\
\text { Chromogranin mostly negative } \\
\text { EZH2 mostly positive }\end{array}$ \\
\hline
\end{tabular}

$T C$ typical carcinoids, $A C$ atypical carcinoids, $L C N E C$ large cell neuroendocrine carcinomas, $S C C$ small cell carcinomas 
Author contributions H.B. and P.S. contributed equally to this manuscript by writing, editing, and critical review of its contents.

Funding Open Access funding enabled and organized by Projekt DEAL.

Declarations This review does not contain primary data and complies with Ethical Standards and the Declaration of Helsinki.

Conflict of interest The authors declare no competing interest.

Open Access This article is licensed under a Creative Commons Attribution 4.0 International License, which permits use, sharing, adaptation, distribution and reproduction in any medium or format, as long as you give appropriate credit to the original author(s) and the source, provide a link to the Creative Commons licence, and indicate if changes were made. The images or other third party material in this article are included in the article's Creative Commons licence, unless indicated otherwise in a credit line to the material. If material is not included in the article's Creative Commons licence and your intended use is not permitted by statutory regulation or exceeds the permitted use, you will need to obtain permission directly from the copyright holder. To view a copy of this licence, visit http://creativecommons.org/licenses/by/4.0/.

\section{References}

1. Alcala N, Leblay N, Gabriel AAG, Mangiante L, Hervas D, Giffon T, Sertier AS, Ferrari A, Derks J, Ghantous A, Delhomme TM, Chabrier A, Cuenin C, Abedi-Ardekani B, Boland A, Olaso R, Meyer V, Altmuller J, Le Calvez-Kelm F, Durand G, Voegele C, Boyault S, Moonen L, Lemaitre N, Lorimier P, Toffart AC, Soltermann A, Clement JH, Saenger J, Field JK, Brevet M, Blanc-Fournier C, Galateau-Salle F, Le Stang N, Russell PA, Wright G, Sozzi G, Pastorino U, Lacomme S, Vignaud JM, Hofman V, Hofman P, Brustugun OT, Lund-Iversen M, Thomas de Montpreville V, Muscarella LA, Graziano P, Popper H, Stojsic J, Deleuze JF, Herceg Z, Viari A, Nuernberg P, Pelosi G, Dingemans AMC, Milione M, Roz L, Brcic L, Volante M, Papotti MG, Caux C, Sandoval J, Hernandez-Vargas H, Brambilla E, Speel EJM, Girard N, Lantuejoul S, McKay JD, Foll M, Fernandez-Cuesta L (2019) Integrative and comparative genomic analyses identify clinically relevant pulmonary carcinoid groups and unveil the supracarcinoids. Nat Commun 10:3407. https://doi.org/10.1038/s41467019-11276-9

2. Bondgaard AL, Poulsen TT, Poulsen HS, Skov BG (2012) Different expression of EZH2, BMI1 and Ki67 in low and high grade neuroendocrine tumors of the lung. Cancer Biomark 11: 123-128. https://doi.org/10.3233/CBM-2012-0269

3. Cardillo G, Treggiari S, Paul MA, Carleo F, De Massimi AR, Remotti D, Graziano P, Martelli M (2010) Primary neuroendocrine tumours of the thymus: a clinicopathologic and prognostic study in 19 patients. Eur J Cardiothorac Surg 37:814-818. https://doi.org/ 10.1016/j.ejcts.2009.10.026

4. Chalabreysse L, Etienne-Mastroianni B, Adeleine P, Cordier JF, Greenland T, Thivolet-Bejui F (2004) Thymic carcinoma: a clinicopathological and immunohistological study of 19 cases. Histopathology 44:367-374. https://doi.org/10.1111/j.1365-2559. 2004.01796.x

5. Chetty R, Batitang S, Govender D (1997) Large cell neuroendocrine carcinoma of the thymus. Histopathology 31:274-276. https:// doi.org/10.1046/j.1365-2559.1997.2380849.x
6. Cowen T, Thrasivoulou C, Shaw SA, Abdel-Rahman TA (1996) Transplanted sweat glands from mature and aged donors determine cholinergic phenotype and altered density of host sympathetic nerves. J Auton Nerv Syst 60:215-224. https://doi.org/10.1016/ 0165-1838(96)90002-8

7. de Perrot M, Spiliopoulos A, Fischer S, Totsch M, Keshavjee S (2002) Neuroendocrine carcinoma (carcinoid) of the thymus associated with Cushing's syndrome. Ann Thorac Surg 73:675-681. https://doi.org/10.1016/s0003-4975(01)02713-8

8. Dinter H, Bohnenberger H, Beck J, Bornemann-Kolatzki K, Schutz E, Kuffer S, Klein L, Franks TJ, Roden A, Emmert A, Hinterthaner M, Marino M, Brcic L, Popper H, Weis CA, Pelosi G, Marx A, Strobel P (2019) Molecular Classification of Neuroendocrine Tumors of the Thymus. J Thorac Oncol 14:1472-1483. https:// doi.org/10.1016/j.jtho.2019.04.015

9. Dutta R, Kumar A, Julka PK, Mathur SR, Kaushal S, Kumar R, Jindal T, Suri V (2010) Thymic neuroendocrine tumour (carcinoid): clinicopathological features of four patients with different presentation. Interact Cardiovasc Thorac Surg 11:732-736. https://doi. org/10.1510/icvts.2010.237651

10. Faviana P, Marconcini R, Ricci S, Galli L, Lippolis P, Farci F, Castagna M, Boldrini L (2019) EZH2 expression in intestinal neuroendocrine tumors. Appl Immunohistochem Mol Morphol 27: 689-693. https://doi.org/10.1097/PAI.0000000000000647

11. Goto K, Kodama T, Matsuno Y, Yokose T, Asamura H, Kamiya N, Shimosato Y (2001) Clinicopathologic and DNA cytometric analysis of carcinoid tumors of the thymus. Mod Pathol 14:985-994. https://doi.org/10.1038/modpathol.3880423

12. Heaphy CM, de Wilde RF, Jiao Y, Klein AP, Edil BH, Shi C, Bettegowda C, Rodriguez FJ, Eberhart CG, Hebbar S, Offerhaus GJ, McLendon R, Rasheed BA, He Y, Yan H, Bigner DD, ObaShinjo SM, Marie SK, Riggins GJ, Kinzler KW, Vogelstein B, Hruban RH, Maitra A, Papadopoulos N, Meeker AK (2011) Altered telomeres in tumors with ATRX and DAXX mutations. Science 333:425. https://doi.org/10.1126/science.1207313

13. Hechtman JF, Klimstra DS, Nanjangud G, Frosina D, Shia J, Jungbluth AA (2019) Performance of DAXX Immunohistochemistry as a Screen for DAXX Mutations in Pancreatic Neuroendocrine Tumors. Pancreas 48:396-399. https:// doi.org/10.1097/MPA.0000000000001256

14. Jiao Y, Shi C, Edil BH, de Wilde RF, Klimstra DS, Maitra A, Schulick RD, Tang LH, Wolfgang CL, Choti MA, Velculescu VE, Diaz LA Jr, Vogelstein B, Kinzler KW, Hruban RH, Papadopoulos N (2011) DAXX/ATRX, MEN1, and mTOR pathway genes are frequently altered in pancreatic neuroendocrine tumors. Science 331:1199-1203. https://doi.org/10.1126/science. 1200609

15. Kim JY, Brosnan-Cashman JA, An S, Kim SJ, Song KB, Kim MS, Kim MJ, Hwang DW, Meeker AK, Yu E, Kim SC, Hruban RH, Heaphy CM, Hong SM (2017) Alternative Lengthening of Telomeres in Primary Pancreatic Neuroendocrine Tumors Is Associated with Aggressive Clinical Behavior and Poor Survival. Clin Cancer Res 23:1598-1606. https://doi.org/10.1158/10780432.CCR-16-1147

16. Kiuru M, Busam KJ (2017) The NF1 gene in tumor syndromes and melanoma. Lab Investig 97:146-157. https://doi.org/10.1038/ labinvest.2016.142

17. Kuo TT, Chang JP, Lin FJ, Wu WC, Chang CH (1990) Thymic carcinomas: histopathological varieties and immunohistochemical study. Am J Surg Pathol 14:24-34

18. La Rosa S, Chiaravalli AM, Placidi C, Papanikolaou N, Cerati M, Capella C (2010) TTF1 expression in normal lung neuroendocrine cells and related tumors: immunohistochemical study comparing two different monoclonal antibodies. Virchows Arch 457:497507. https://doi.org/10.1007/s00428-010-0954-0 
19. Lim LC, Tan MH, Eng C, Teh BT, Rajasoorya RC (2006) Thymic carcinoid in multiple endocrine neoplasia 1: genotype-phenotype correlation and prevention. J Intern Med 259:428-432. https://doi. org/10.1111/j.1365-2796.2006.01619.x

20. Mega S, Oguri M, Kawasaki R, Hazama K, Iwai K, Kondo S (2008) Large-cell neuroendocrine carcinoma in the thymus. Gen Thorac Cardiovasc Surg 56:566-569. https://doi.org/10.1007/ s11748-008-0299-7

21. Millar GT (1969) Guanethidine drops in thyroid eye disease. Trans Ophthalmol Soc U K 88:677-679

22. Moran CA, Suster S (2000) Neuroendocrine carcinomas (carcinoid tumor) of the thymus. A clinicopathologic analysis of 80 cases. Am J Clin Pathol 114:100-110. https://doi.org/10.1309/3PDN-PMT5EQTM-H0CD

23. Moran CA, Suster S (2000) Thymic neuroendocrine carcinomas with combined features ranging from well-differentiated (carcinoid) to small cell carcinoma. A clinicopathologic and immunohistochemical study of 11 cases. Am J Clin Pathol 113:345-350. https://doi.org/10.1309/Q01U-60BL-VEV4-TWR1

24. Nagata Y, Ohno K, Utsumi T, Sasaki Y, Suzuki Y (2006) Large cell neuroendocrine thymic carcinoma coexisting within large WHO type AB thymoma. Jpn J Thorac Cardiovasc Surg 54:256-259. https://doi.org/10.1007/p100022248

25. Ogawa F, Iyoda A, Amano H, Nezu K, Jiang SX, Okayasu I, Satoh Y (2010) Thymic large cell neuroendocrine carcinoma: report of a resected case - a case report. J Cardiothorac Surg 5:115. https://doi. org/10.1186/1749-8090-5-115

26. Papaxoinis G, Lamarca A, Quinn AM, Mansoor W, Nonaka D (2018) Clinical and Pathologic Characteristics of Pulmonary Carcinoid Tumors in Central and Peripheral Locations. Endocr Pathol 29:259-268. https://doi.org/10.1007/s12022-018-9530-y

27. Rieker RJ, Aulmann S, Penzel R, Schnabel PA, Blaeker H, Esposito I, Morresi-Hauf A, Otto HF, Hecker E, Dienemann H, Schirmacher P, Mechtersheimer G (2005) Chromosomal imbalances in sporadic neuroendocrine tumours of the thymus. Cancer Lett 223:169-174. https://doi.org/10.1016/j.canlet.2004.10.027

28. Rinke A, Gress TM (2017) Neuroendocrine Cancer, Therapeutic Strategies in G3 Cancers. Digestion 95:109-114. https://doi.org/10. $1159 / 000454761$

29. Shoji T, Fushimi H, Takeda S, Tanio Y (2011) Thymic large-cell neuroendocrine carcinoma: a disease neglected in the ESMO guideline? Ann Oncol 22:2535. https://doi.org/10.1093/annonc/mdr415

30. Soga J, Yakuwa Y, Osaka M (1999) Evaluation of 342 cases of mediastinal/thymic carcinoids collected from literature: a comparative study between typical carcinoids and atypical varieties. Ann Thorac Cardiovasc Surg 5:285-292

31. Strobel P, Marx A, Chan JK, Marom EM, Matsuno Y, Nicholson AG, Travis W (2015) Typical and atypical carcinoid. In: Travis W, Brambilla E, Burke AP, Marx A, Nicholson AG (eds) WHO classification of Tumours of the lung, pleura, Thymus and Heart. IARC Press, Lyon, pp 234-238

32. Strobel P, Zettl A, Shilo K, Chuang WY, Nicholson AG, Matsuno Y, Gal A, Laeng RH, Engel P, Capella C, Marino M, Chan JK, Rosenwald A, Travis W, Franks TJ, Ellenberger D, Schaefer IM, Marx A (2014) Tumor genetics and survival of thymic neuroendocrine neoplasms: a multi-institutional clinicopathologic study.
Genes Chromosom Cancer 53:738-749. https://doi.org/10.1002/ gcc. 22183

33. Sturm N, Rossi G, Lantuejoul S, Papotti M, Frachon S, Claraz C, Brichon PY, Brambilla C, Brambilla E (2002) Expression of thyroid transcription factor-1 in the spectrum of neuroendocrine cell lung proliferations with special interest in carcinoids. Hum Pathol 33:175-182. https://doi.org/10.1053/hupa.2002.31299

34. Suster S, Moran CA (2001) Neuroendocrine neoplasms of the mediastinum. Am J Clin Pathol 115 Suppl:S17-S27. https://doi.org/ 10.1309/L38W-8P9X-X142-3N78

35. Teh BT, Zedenius J, Kytola S, Skogseid B, Trotter J, Choplin H, Twigg S, Farnebo F, Giraud S, Cameron D, Robinson B, Calender A, Larsson C, Salmela P (1998) Thymic carcinoids in multiple endocrine neoplasia type 1. Ann Surg 228:99-105. https://doi.org/ 10.1097/00000658-199807000-00015

36. Tiffet O, Nicholson AG, Ladas G, Sheppard MN, Goldstraw P (2003) A clinicopathologic study of 12 neuroendocrine tumors arising in the thymus. Chest 124:141-146. https://doi.org/10.1378/ chest.124.1.141

37. Uccella S, La Rosa S, Volante M, Papotti M (2018) Immunohistochemical biomarkers of gastrointestinal, pancreatic, pulmonary, and thymic neuroendocrine neoplasms. Endocr Pathol 29:150-168. https://doi.org/10.1007/s12022-018-9522-y

38. Wen J, Chen J, Chen D, Liu D, Xu X, Huang L, Cao J, Zhang J, Gu Y, Fan M, Chen Y (2018) Evaluation of the prognostic value of surgery and postoperative radiotherapy for patients with thymic neuroendocrine tumors: A propensity-matched study based on the SEER database. Thorac Cancer 9:1603-1613. https://doi.org/10. 1111/1759-7714.12868

39. Wick MR, Scheithauer BW, Weiland LH, Bernatz PE (1982) Primary thymic carcinomas. Am J Surg Pathol 6:613-630. https:// doi.org/10.1097/00000478-198210000-00003

40. Wong LH, McGhie JD, Sim M, Anderson MA, Ahn S, Hannan RD, George AJ, Morgan KA, Mann JR, Choo KH (2010) ATRX interacts with $\mathrm{H} 3.3$ in maintaining telomere structural integrity in pluripotent embryonic stem cells. Genome Res 20:351-360. https:// doi.org/10.1101/gr.101477.109

41. Yachida S, Vakiani E, White CM, Zhong Y, Saunders T, Morgan R, de Wilde RF, Maitra A, Hicks J, Demarzo AM, Shi C, Sharma R, Laheru D, Edil BH, Wolfgang CL, Schulick RD, Hruban RH, Tang LH, Klimstra DS, Iacobuzio-Donahue CA (2012) Small cell and large cell neuroendocrine carcinomas of the pancreas are genetically similar and distinct from well-differentiated pancreatic neuroendocrine tumors. Am J Surg Pathol 36:173-184. https://doi.org/10. 1097/PAS.0b013e3182417d36

42. Yoshikawa T, Noguchi Y, Matsukawa H, Kondo J, Matsumoto A, Nakatani Y, Kitamura H, Ito T (1994) Thymus carcinoid producing parathyroid hormone (PTH)-related protein: report of a case. Surg Today 24:544-547. https://doi.org/10.1007/BF01884576

43. Zaleski M, Kalhor N, Moran CA (2020) Typical and atypical carcinoid tumors of the mediastinum: a biomarker analysis of 27 cases with clinical correlation. Int J Surg Pathol:1066896920976845. https://doi.org/10.1177/1066896920976845

Publisher's note Springer Nature remains neutral with regard to jurisdictional claims in published maps and institutional affiliations. 